\title{
ESSENTIALS OF CASE TREATMENT WITH DELINQUENT CHILDREN
}

\author{
By Henry W. Thurston, \\ Member of Staff, The New York School of Philanthropy.
}

So far as case treatment of delinquent children depends upon the authority of courts it is necessarily limited and colored by the provision of the law establishing those courts; by the personality and judicial methods of the judges; and by the public opinion that created and sustains the laws. It is, therefore, a first requisite to continuous good case treatment of juvenile delinquents that there be a right attitude of the public mind, and that this attitude be expressed in laws and court procedure which will permit and encourage good case treatment of the individual delinquent. A brief reference to the public opinion which found legal expression in the Roman law, the penal code of France and the English common law, compared with the American law which in many states gives a juvenile court chancery jurisdiction, will illustrate the necessity of a right attitude of the public mind towards young offenders as a basis for right case treatment.

\section{The Basis of Case Treatment in Public Opinion and Law}

The Roman criminal law treated the adult differently from the child by making a gradation from non-punishability-seven years, through stages of "impuberes" (for boys till 14, for girls till 12) and "minority" to full maturity at 25 years. The amount of punishment varied according to these gradations in age though not by a definite scale. There was no special judicial procedure or special punitive institutions for juvenile offenders.

The penal code of France similarly distinguished between an adult and a child, placing the dividing line at 16 years. For offenders under 16 , the law provided that if a child acted without "discernement" he was to be acquitted and either returned to his parents or sent to a house of correction for a definite time which must end when the offender reached the age of 20 years. If the offender under 16 acted with "discernement" he was to be pun131 
ished to a less degree than an adult according to a graduated scale. There was no minimum age for punishability and no special judicial procedure.

The common law of England which has been followed by the statute laws of many American states gave seven years as the lowest limit of punishability. Above this age and below maturity during most of the nineteenth century, England and the United States have graded punishment according to the judicial opinion of the degree of responsibility of the young offender for his offense. Of this groping of the Roman, French and English public opinion toward discrimination in the treatment of juvenile offenders, as expressed in their laws, Philip Klein says:

The law went half way toward treatment of the cause in acknowledging that lack of responsible, mature thinking is partly the cause of the offense, and in establishing the presumption of only partial responsibility in the case of juveniles, but failed to go the rest of the way, however, to find that youthfulness being the cause of the lowered responsibility, it was this youthfulness or immaturity that had to be dealt with, rather than the remaining amount of responsibility. . . . .

Though technically an offender against the law (the child) is really primarily a neglected child. Because of his irresponsibility and immaturity the child needs protection and training. When no protection and training are given the child it is likely to act upon its own impulses, and these, often, in cases of destitution nearly always, take the form of an offense against the law. ${ }^{1}$

The same attitude of public opinion as formulated in law is authoritatively expressed by Judge Julian W. Mack.

The underlying conception of our criminal law, despite all the reforming influences that have come in, is still that of vindication, that the state must vindicate by punishing. This ought to be completely eliminated when we deal with children. . . . . A child who has committed an offense, no matter what the nature of the offense may be-even what we call murder-should be dealt with by the state, not as an adult is, merely to punish, but for the purpose of correction, for the purpose of training, for the purpose of education.2

That courts in states where public opinion toward juvenile delinquents has not yet become formulated in chancery law and in judicial practice for children's courts, are handicapped in their efforts to develop social case treatment of children, the testimony of Presiding Justice Franklin Chase Hoyt bears convincing testimony.

s "The Treatment of the Delinquent Child in the United States," an unpublished paper which traces the trend above summarized.

2 Address before Judiciary Committee of the Constitutional Convention of New York State, June 29, 1915. 
One of the handicaps which retards the Children's Court development at present is the impossibility of obtaining a comprehensive method of legal procedure under constitutional conditions. The court should have broader powers, and the present system of trials in children's cases should be done away with.

It savors too much of the strict, narrow, criminal trial. If chancery or equity powers could be conferred on the court it would be possible to inquire into the facts and circumstances of each case at the first hearing to see whether the child is in need of the care and protection of the state without first having to make a technical finding of juvenile delinquency. ${ }^{3}$

Social case treatment of juvenile delinquents needs first of all, then, the backing, not only of public opinion but of public opinion formulated in law and carried out in practice. A second need, hardly less essential, is a similar public opinion formulated in law and judicial procedure which makes it possible that adults who are responsible for the neglect and delinquency of children can be reached either directly by the juvenile court, or by another court on the initiative of the juvenile court. In practice this means one of three things.

(a) A juvenile court with jurisdiction over adults in their domestic relations and in other cases of adults involving children.

(b) A domestic relations court with jurisdiction in case of juvenile delinquents.

(c) Two courts, one for juveniles and one for adults in close administrative coöperation.

\section{Case Treatment from the Time of the Offense until a Delinquent Is Placed on Probation}

There are two primary essentials in good case treatment during this stage. First, the delinquent should be so treated that the process itself tends to make him better. For example, if personal custody away from his home is necessary, that it shall be in separation from offenders and custodians who incite him to further wrong and in company with those who call out what is good in him. If home custody pending court hearing is even reasonably sure of producing the delinquent when wanted, and is not of itself a further encouragement to delinquency, it should be allowed. The second essential is that all the pertinent facts be found out, not only about the offense but about the offender and his habitual experiences and activities.

The approved procedure from the time of the offense to the time

${ }^{3}$ Annual Report of the Children's Court of the City of New York, 1916, p. 36. 
the delinquent is put upon probation (or dismissed or committed to an institution) is suggested by the following typical case:

Three boys during their habitual street activities of a Saturday forenoon found out that the grocer was away for the day and that the transom was open. They agreed to go home to luncheon and to meet at 1.30 and go into the store. This they did, thus becoming in the eyes of the law burglars and thieves. They carried off sweet chocolate, Nabiscoes, cigarettes, gum, candy, cookies, etc., and hid their booty in a shanty back of one of their houses. The next day, Sunday, they went far into the open country and ate their plunder. Meanwhile a smaller boy who had seen the burglary told on them. On Monday the policeman filed a petition for each of the three boys with the clerk of the juvenile court. This petition stated on oath that (name, age, address of boy) to the best of the knowledge and belief of the petitioner is a delinquent boy in that (description of the offense). The clerk acting for the judge then issued a summons upon the parents of these boys, stating that petitions had been filed charging them with delinquency and that a hearing had been set on a certain day and hour in the juvenile court, and directing that they appear at that time with the boys.

Pending this hearing a probation officer made an investigation of all the necessary personal, developmental, family, neighborhood, and school facts relating to the boys, so that the habitual activities, trend and opportunities of each boy became clear. The boys were also examined by a doctor and a mental specialist.

Specialists in the study of delinquents agree that the short period between the detection of a child in delinquency and the hearing before a judge who is to decide what is to be done with him is the best psychological time to secure the maximum degree of coöperation of the juvenile delinquent in efforts to understand the real reasons for his own misconduct and the essentials of the best plans to prevent recurrence of wrong-doing.

In cases such as the above, with all these facts summarized in writing,-so that the judge can visualize not only the particular offense but the personality, habitual life, and future opportunities of the child,- the parents, the child, the probation officer, the complainant, friends and witnesses file up and stand before the judge. Here there are as many different variations in procedure as there are different judges and juvenile delinquents, but good case treatment 
demands of the judge that when the hearing is ended he shall have produced certain very definite impressions on the delinquent and on his parents and friends:

1. That they have had "a square deal" and a fair chance to tell the judge whatever seems to them important.

2. That the judge has found out the real facts-that nobody has "put one over on him."

3. That in his decision, even to commit to an institution, he acted not in anger or in an arbitrary way, but so far as his duty as a judge and the law permit, from a desire to help the offender "to do better" - " to give him a real chance."

4. That if the delinquent is put on probation the judge has made clear that the probation officer is his representative who, like the judge, is not easily fooled and will always give a square deal.

Unless a majority of those who file out of the court room have in substance received the above four impressions, the judge has lost much of his psychological opportunity to make his contribution to good case treatment of juvenile delinquents.

In this process the juvenile court judge who is compelled to work under the criminal court law is sadly handicapped for the reasons that at the first hearing all that can be taken is testimony for and against the delinquency of the child; and that a remand of the case for a second hearing is necessary in order to secure the social investigation and physical and mental diagnosis upon which alone a sound plan of action can be based and stated in the decision by the judge. In short the judge is almost compelled either to decide upon a plan of treatment, on incomplete information, or to call the child and his parents back for a second hearing after he has had time to have the necessary facts collected.

A decision upon insufficient information tends to the impression upon the child and his family either that they did not get a square deal or that the judge was fooled. A remand for an investigation often works real hardships upon poor people in causing loss of time and money and seems to them unfair. The remand also sometimes arouses contempt for a court that calls the child and his parents to its bar without knowing or getting at all the facts in the case. In other words, it is harder for a judge under a criminal court procedure to send a majority of children and adults out of his court feeling both that they have had a square deal and that the judge cannot be easily fooled than it is for a judge under the chancery law. 
This is true even if the average decisions of the two judges are equally wise from a case treatment point of view.

Returning now to the decisions of the judge re the three boys who were mentioned above as having burglarized a store on a Saturday afternoon and who had been brought into court on petition and summons as before described, after all the necessary facts had been found out before the hearing, the judge was able to produce the four impressions above emphasized as important, although he made a different decision in each case. The investigation in the case of No. 1 showed a normal nine-year-old boy from a good home. He was mischievous and active but not vicious. He was in fourth grade in school and regular in attendance. His parents not only had a good home but now that they were alert to the need of more careful plans and supervision for his spare time, were able to connect him with Boy Scouts and probably to secure a change of behavior without further aid from the court. The judge, therefore, dismissed him to the care of his parents.

The facts in case No. 2 were that he was a twelve-year-old boy in the sixth grade. The father had deserted and the mother and boy were living with the boy's grandfather who ran a milk depot and route. The boy helped some in spare time but was much on the street. Once, after saving money for months, he had run away with other boys who planned to go south where they could see "tropical fruits and waving grain." The judge, therefore, explained that he would allow the boy to continue at home on condition that he and his mother and grandfather and the probation officer would work together to prevent further wrong-doing. He was to be kept busy and happy, not only at his work, but also during his spare time activities, which thus far had been unsupervised.

The facts in case No. 3 were that the boy had previously been in trouble for truancy and also for joining with other boys in stealing inner tubes of automobile tires from a shed used as a garage. His mother was dead and his stepmother was afraid of being too hard on him. The father was brutally severe at times but away from home most of each week. The judge explained that he must see that this boy's habits and home were changed and that the boy's best chance to reform was in an institution unless a family home under more favorable conditions was possible. At this point an older brother who was married and whose home had been visited 
by the probation officer offered his home, his personal service and new school associations, together with membership in a Junior Y. M. C. A. which offered swimming and other recreations. Accordingly No. 3 was put on probation to live at the home of his brother.

In a group case like this some judges are careful to have only one delinquent and his friends present at the time his decision is given, but even if all three boys and their friends are present, the emphasis of the judge, not alone upon the wrong-doing of each, but upon such conditions of home, play, school and work opportunity and supervision as will give each boy a real chance to conquer his delinquent tendencies, gives all an impression of a square deal in the light of facts as they are. Good case treatment of several delinquents who have been caught in the same offense does not often demand identical decisions by the judge, but usually a different decision in some particular for each. To the degree that the differences in decisions are based on accurate knowledge of facts, understood by the delinquents themselves as well as by the judge, they and their friends will approve these variations in decision. Such variations in the judge's decisions, however, are not likely to be approved by the delinquents and their friends if the major emphasis, as is too often true in criminal courts, is laid on the offense rather than on the task before each offender of so living in future that no other offense will be committed.

\section{Case Treatment by the Probation Officer}

The case treatment now passes into the hands of the probation officer. The equivalent of the first interview (in family cases needing a social worker), of investigation, of analysis of facts, of diagnosis, and of the formation of the outlines of a plan has already been taken.

It is now the task of the probation officer to work out with the delinquent and his parents or guardians the details of a course of life and conduct that will lead to prevention of further delinquency and to right habits and ideals of life. Right here is where too many probation officers fail to do good work. The delinquent knows he has done wrong. He usually has at least a brief desire and intention to do right. What he needs and his parents need is a clear but elastic program for the week which will give the delinquent such good 
times as boys and girls ought to have, without constant temptations to evil and further delinquency. In other words he needs a possible program of things to do which seem to the delinquent worth doing in all his spare time. To this end a careful study of the resources of home, school, playground, club, park, library, etc., needs to be made by the probation officer, the delinquent and his parents, until it is clear how a week can be spent without doing wrong and yet in such ways that the delinquent can enjoy most of it. Unless such a program can be fairly definitely, but with great elasticity, laid, out and approved by the delinquents, the chances for overcoming serious delinquencies are poorer than they ought to be.

It is essential to the success of probationary care of delinquents that they be helped to see and to choose possible right courses of action at the precise points where before they have once, or frequently, chosen wrong courses of action. It is plainly futile to expect reform under probation unless the child himself can be led to see and feel that right action is not only possible but worth while from his own point of view. Not alone what the probation officer thinks is right and desirable for the child, but what the delinquent himself can be led to see is right, desirable and possible, will be really effective in changing his behavior. To this end the relation of probation officers to probationers must become one of reciprocal confidence and sympathy. Underneath this, but rarely used, is of course the authority of the court. The probation officer should also have such an intimate knowledge of the habitual life of the delinquent at school, at home, in playground, street, and spare time, that the delinquent will feel the probation officer, while his friend, cannot be fooled.

Whether the probation officer should be the same person who made the investigation of the delinquent's home and habits for the hearing is a secondary question. The success of a good probation officer depends upon his skill in influencing the probationer and changing wrong behavior into right behavior, not on the mere fact that he came into the life of the delinquent before or after the hearing before the judge.

A similar question is that of reporting to the probation officer by the probationer. In some way the delinquent must be led to act honestly and on his own responsibility toward his own reform. In many cases to report to the probation officer at a certain time and 
place tends to develop his honesty and sense of responsibility. The probation officer must, however, have many other sources of information and means of guidance of the probationer. If he relies on the report alone, he will often be fooled and his influence be reduced to less than nil. Good case treatment means an adoption of available means to the end that habit and voluntary behavior become right with each child. No general rules are applicable to all cases of sick morals any more than to sick bodies. Until a probation officer learns this he is not so successful as he ought to be.

The application of this principle of individualization of treatment explains what the right time and method of ending the probation period are. If opportunities for right choices of behavior for 24 hours a day for seven days in the week are found impossible for a delinquent in his home and neighborhood; or if, although good choices are possible, his actual choices are habitually wrong, the probationary period ought to end by commitment so that control may be enforced, or by some change of environment or supervision that promises progress toward reform. On the other hand, when not only real opportunities for right choices of behavior have been seen by the delinquent but he has learned to choose them for himself, the probation officer should give the delinquent the encouragement of knowing that the authority of the court has been ended. Likewise this termination of probation should be entered on his record at the court. He should know that henceforth he is thought strong enough to do right with merely the personal encouragement of the probation officer. Whether or not this close of the period of probation shall be celebrated by having the delinquent released in person by the judge cannot be stated without knowledge of the case. Plainly some girls who have left sex offenses far in their past, should not be compelled to go again to court. Good case treatment of delinquents demands, at the close, as at the beginning and all through, that the process of release from probation should be not a matter of cold routine, but an act of "constructive friendship."

The final step is that the probation officer should be a voice in his community urging, in season and out of season, the suppression of causes and conditions which make for delinquency and also urging with still greater earnestness the provision of adequate facilities and agencies that make for wholesome juvenile life and education. 